TADEUSZ LEWASZKIEWICZ

Uniwersytet im. Adama Mickiewicza w Poznaniu

\title{
Wybór tekstów. Z dziejów języka polskiego. Do polowy XIX w. (Tom 1), (...). Od polowy XIX w. (Tom 2), pod redakcją Marka Cybulskiego, Wydawnictwo Uni- wersytetu Lódzkiego, Lódź 2015, ss. 630+688
}

W dwutomowej chrestomatii (liczącej ponad 1300 stron) znajduje się prawie 600 (tj. 583) całych lub fragmentarycznych tekstów - staropolskich, średniopolskich i nowopolskich (aż po rok 2013). Wybór tekstów (...) powstał w wyniku współpracy Katedry Historii Języka Polskiego Uniwersytetu Łódzkiego oraz Zakładu Historii i Pragmatyki Języka Polskiego i Zakładu Komunikacji Językowej Uniwersytetu Zielonogórskiego. W przygotowaniu antologii uczestniczyło 20 pracowników z obu uniwersytetów. Redaktorem naukowym obszernej książki jest prof. Marek Cybulski. Dotychczas ukazało się już kilka chrestomatii tekstów polskich (Stefana Vrtela-Wierczyńskiego, Wiesława Wydry i Wojciecha Ryszarda Rzepki, Wacława Twardzika, Witolda Taszyckiego oraz Teresy Skubalanki, Marii Wojtak i Jerzego Bartmińskiego), ale najnowsza chrestomatia różni się znacznie od poprzednich pod względem objętości, zasięgu chronologicznego i koncepcji prezentowania tekstów. Skromniejszą publikacją była również chrestomatia Stanisława Borawskiego i Antoniego Furdala (Wybór tekstów do historii języka polskiego, Warszawa 1980), chociaż znajdowały się w niej teksty reprezentujące wszystkie epoki historii języka polskiego.

We Wstepie M. Cybulski informuje m.in. o doborze tekstów i reprezentowanych przez nie stylach funkcjonalnych, o sposobach prezentacji tekstów (w tym o zasadach transliteracji i symbolach edytorskich), o strukturze komentarzy, słowniczkach zamieszczonych po komentarzach.

Przed każdym tekstem znajduje się jego opis bibliograficzny, informacja o miejscu przechowywania rękopisu, o zastosowanym typie transliteracji itd. Po tekście następuje komentarz oraz zwykle (szczególnie przy tekstach starszych) objaśnienie znaczeniowe trudniejszych wyrazów. W komentarzach znajdujemy nie tylko informacje o autorach, rękopisach, drukach, podstawie translacji, ale również charakterystykę pisowni, osobliwości gramatyki i stylu. Bogactwo treści w komentarzach dosyć często wręcz zdumiewa.

Z tekstu zamieszczonego na okładce chrestomatii warto zacytować ważny fragment:

Książka umożliwia śledzenie ewolucji stylów funkcjonalnych, społecznych odmian języka, świadomości językowej i wiedzy o języku. Informuje o sytuacji językowej w Polsce, o polityce językowej Polaków i wobec Polaków. Pokazuje ewolucję fonetyki, gramatyki, słownictwa i ortogra- 
fii. Teksty opatrzono omówieniami zjawisk, które w nich wystąpiły lub które stanowiły dla nich konteksty. Wyjaśnienia te umieszczono w komentarzach, przypisach, słownikach i w indeksie.

Teksty reprezentują różne style funkcjonalne: artystyczny, potoczny (np. pamiętniki, dialogi stylizowane na język potoczny, nagrane wypowiedzi), urzędowy (np. roty przysiąg sądowych, protokoły, obwieszczenia władz, umowy kupna-sprzedaży), naukowy (teksty reprezentujące różne działy nauki), gatunki użytkowe (np. modlitwy codzienne, przemówienia, gatunki publicystyczne - artykuły i wiadomości prasowe, felietony, wywiady, ogłoszenia, reklamy itd.). Stosunkowo mało jest tekstów literackich, ponieważ dostęp do nich nie jest trudny.

Z obu tomów przytoczę kilkadziesiąt tytułów tekstów, aby zwrócić uwagę na bogatą zawartość omawianego wydawnictwa. Oto ich wykaz: Psalterz floriański (1398-1399); Chytrze bydla z pany kmiecie ... (ok. 1483); Jan Konarski, Mowa powitalna (między 1512 a 1515); List do burmistrza i rajców miasta Bardiowa (1530); Lustracja miasta Bolimowa (1564); Mikołaj Rej, Źwierciadło (1567-1568); Jakub Wujek, Psalmy 50 (51) i 137 (1599); [Umowa sprzedaży - kupna] (1616); [Testament mieszczanki] (1624); [Ćwiczenia uczniowskie] (1628); [Pozew sąowy] (1658); Błażej Lipowski, Piechotne ćwiczenie ... (1660); Elżbieta Sieniawska, [Uniwersał] (1728); Mowa posła na sejmie (ok. 1760); Franciszek Zabłocki, Fircyk w zalotach (1781); Józef Mroziński, Odpowiedź na [...] recenzję (1824); Adam Mickiewicz, Pan Tadeusz (1834); Michał Starzewski [Traktat o szermierce] (ok. 1840); [Nekrologi z prasy poznańskiej] (1850); Józef Bełza, Krótki rys chemii ... (1852); Henryk Sienkiewicz, Potop (1886); Stanisław Rewiński, [Sposoby tępienia szczurów] (1887); Jan Rozwadowski, Językoznawstwo a język literacki (1913); Józef Piłsudski, Przemówienie (1914); List majstrowski (1925); [Ogłoszenie - repertuar kina] (1927); [Odezwa Komunistycznej Partii Polski] (1932); Wyciag ze statutu kasy oszczędności (1938); Józef Kostrzewski, Pradzieje człowieka (1950); Stanisław Urbańczyk, Polskość nazw miejscowych (1950); List Stanisława Lema do Stawomira Mrożka (1969); Ubezpieczenie kontraktowe trzody chlewnej mięsno-słoninowej (1970); Marian Mazur, Cybernetyka i charakter (1976); I sekretarz KC PZPR z wizyta (1979); Wisława Szymborska, Pogrzeb (1986); Uchwała Sądu Najwyższego (1996); Konstytucja Rzeczypospolitej Polskiej (1997); [Listy czytelników do redakcji] (2006-2007); Ulotka dla pacjenta (2011); Kibole Legii chcieli wykoleić pociag z kibicami Jagiellonii (2012); Stanowisko Komitetu Językoznawstwa PAN (2012); Sonda uliczna. Pakol pyta: Po co żyjesz (2013).

$\mathrm{Na}$ końcu drugiego tomu publikacji zamieszczono Bibliografie (s. 652-666), Indeks (s. 667-668) i Indeks czasopism (s. 688-689). Bibliografia obejmuje: wybory tekstów, słowniki, opracowania ogólne (15 pozycji) i inne opracowania - książki i artykuły (ponad 300 pozycji). Wykaz literatury naukowej można uznać za podstawową bibliografię historii języka polskiego. Cenny jest również indeks, w którym znajdują się nazwy własne (np. Mączyński Jan, Kraków, Mazury), nazwy instytucji ważnych w rozwoju języka polskiego, tytuły czasopism i przede wszystkim wyrazy i połączenia wyrazowe - w większości o charakterze terminów (np. etykieta językowa, funkcja fatyczna, hiperonim, hiperyzm, koherencja, kondensacja treści, megalomania językowa, metonimia, niejednorodność stylistyczna, perlokucyjny efekt, pole semantyczne (znaczeniowe), przysłowie, retoryczność, styl, świadomość językowa, wydwarzanie). Haseł podstawowych jest około 1500. Jeśli się jednak weźmie pod uwagę hasła o charakterze połączeń wyrazowych (zamieszczone w obrębie 
haseł głównych, np. pod hasłem słownictwo: - abstrakcyjne, - ekspresywne, - emocjonalne itd. - razem 25 wyrażeń), to jest ich łącznie w całym indeksie zapewne prawie dwa tysiące. Liczby po hasłach indeksu odsyłają do odpowiedniego numeru tekstu. Lektura indeksu, który oparty jest na komentarzach zamieszczonych przed tekstami i głównie po tekstach, uzmysławia czytelnikowi fakt, że autorzy komentarzy wykorzystali najnowszą wiedzę z historii języka polskiego i z językoznawstwa teoretycznego.

Omówiony wybór tekstów przygotował zespół 20 osób. Warto jednak pamiętać o tym, że aż $66,5 \%$ komentarzy przed tekstami i $64,4 \%$ znacznie ważniejszych komentarzy po tekstach opracował prof. Marek Cybulski, który także jest autorem niemal wszystkich słowników zamieszczonych pod poszczególnymi tekstami. Oprócz tego M. Cybulski zajmował się całością jako redaktor naukowy chrestomatii.

Uważam, że obecnie jest to największa i najlepsza chrestomatia w językoznawstwie słowiańskim. Warto w przyszłości podjąć trud ustalenia, ile języków niesłowiańskich ma wybór tekstów z historii języka na podobnym poziomie. 